\title{
PELATIHAN PERSIAPAN UMKM BINAAN KADIN JAWA BARAT MENGHADAPI FASE NEW NORMAL PASCA PANDEMIK COVID-19
}

\author{
${ }^{1 *}$ Sakina Ichsani, ${ }^{2}$ Helin G. Yudawisastra, ${ }^{3}$ Kharisya Ayu Effendi \\ Universitas Widyatama \\ Email : ${ }^{1}$ sakina.ichsani@,widyatama.ac.id
}

Manuskrip: Okt-2020; Ditinjau: Okt-2020; Diterima: Nov-2020; Online: Jan-2021; Diterbitkan: Jan-2021

\begin{abstract}
ABSTRAK
Pandemi COVID-19 telah mempengaruhi tatanan hidup dan kebiasaan masyarakat di dunia pada umumnya dan di Indonesia pada khususnya. Masyarakat yang pada kesehariannya telah terbiasa untuk berinteraksi secara langsung, karena adanya COVID-19 maka masyarakat harus mulai terbiasa dengan pola hidup dengan social distancing. UMKM menjadi salah satu sektor yang terpuruk akibat pandemi Covid-19. Metode pelaksanaan adalah dengan memberikan pengajaran lewat daring yaitu menggunakan aplikasi googlemeet dan kemudian dilanjutkan dengan melakukan forum diskusi tanya jawab dengan mitra yang tergabung dalam KADIN Jawa Barat. Pada era new normal, UMKM mampu meningkatkan konsumsi nasional yang selanjutnya akan berdampak pada pertumbuhan ekonomi nasional. Strategi yang dapat di terapkan oleh UMKM dalam menghadapi kondisi new normal adalah dengan melakukan penyesuaian transaksi bisnis perusahaan yang bersifat konvensional dan memanfaatkan berbagai jejaring social sehingga akan membuat kontak fisik akan berkurang. Perusahaan juga dapat mengadopasi panduan keselamatan kerja yang tetap memberikan rasa aman dan nyaman bagi karyawan dan konsumen.
\end{abstract}

\section{Kata Kunci: Pandemi COVID-19, New normal, UMKM}

\section{PENDAHULUAN}

Pandemi COVID-19 telah mempengaruhi tatanan hidup dan kebiasaan masyarakat di dunia pada umumnya dan di Indonesia pada khususnya. Masyarakat yang pada kesehariannya telah terbiasa untuk berinteraksi secara langsung, karena adanya COVID-19 maka masyarakat harus mulai terbiasa dengan pola hidup dengan social distancing. Social distancing merupakan suatu tindakan yang dilakukan oleh masyarakat pada setiap kegiatannya dengan melakukan pemisahan jarak sehingga diharapkan tidak terjadi kontak fisik secara langsung yang dapat mengakibatkan adanya pertukaran virus, penyakit dan lainnya.

Adanya COVID-19 juga telah mempengaruhi kegiatan perekonomian. Perkiraan kinerja perekonomian Indonesia sampai akhir tahun 2020 hanya akan sebesar tumbuh 4,56\%. Pertumbuhan ini lebih rendah dibandingkan capaian pertumbuhan tahun 2019 sebesar 5,02\%. Penurunan pertumbuhan ini disebabkan 
oleh pandemik COVID-19 yang mengakibatkan menurunannya pertumbuhan perekonomian di seluruh dunia dan terjadinya penurunan daya beli masyarakat.

Sebagai akibat dari adanya pandemik COVID-19 dan diberlakukannya social distancing berupa PSBB (Pembatasan Sosial Berskala Besar), maka perekonomian secara umum melemah. Namun kegiatan perekonomian di Indonesia diharapkan dapat bisa kembali beroperasi mulai bulan Juni 2020 seiring dengan dilonggarkannya PSBB. Fase new normal adalah suatu fase dimana telah diberlakukanpelonggaran PSBB namun mengakibatkan perubahan tatanan hidup bermasyarakat.

UMKM menjadi salah satu sektor yang terpuruk akibat pandemi Covid19. Pandemik ini hampir melumpuhkan roda perekonomian dalam negeri seiring tingginya ancaman terhadap masyarakat lantaran kehilangan pendapatan rumah tangga karena tidak bisa bekerja akibat maraknya pemutusan hubungan kerja dan kebijakan PSBB. Tantangan untuk UMKM saat ini diantaranya adalah banyak perusahaan yang masih belum memahami cara untuk mengalihkan usaha mereka menjadi digital dikarenakan kurangnya pemahaman tentang teknologi. Kemudian perusahaan mengalami masalah di sisi keuangan dikarenakan perputaran kas yang melambat.

\section{METODE PELAKSANAAN KEGIATAN}

Metode pelaksanaan adalah dengan memberikan pengajaran lewat daring yaitu menggunakan aplikasi googlemeet dan kemudian dilanjutkan dengan melakukan forum diskusi tanya jawab mengenai permasalahan yang dihadapi ketika terjadi pandemi COVID-19 dan upaya yang akan dilakukan ketika memasuki tahap new normal. Forum diskusi tanya jawab ini diharapkan menjadi sarana penghubung antara tutor dari Fakultas Ekonomi dan Bisnis Universitas Widyatama dan mitra KADIN Jawa Barat.

Tahap pertama pelaksanaan kegiatan adalah dengan melakukan peninjauan lapangan dan berkoordinasi dengan mitra. Dalam hal ini dosen pengabdi berkoordinasi dengan para pengambil kebijakan di KADIN Jawa Barat untuk memetakan masalah yang dihadapi oleh para mitra secara umum.

Tahap kedua pelaksanaan pengabdian kepada masyarakat ini adalah dengan mengajukan proposal pengabdian kepada masyarakat guna mendapatkan izin secara tertulis dari pihak universitas dan mendapatkan izin tertulis dari pihak mitra yakni diwakili oleh KADIN Jawa Barat.

Tahap ketiga yaitu setelah melakukan peninjauan lapangan dan mengajukan proposal, maka dilakukan social mapping untuk setiap peserta dengan memberikan kuesioner yang bersifat tertutup. Social mapping ini berguna agar para tutor mendapatkan gambaran mengenai permasalahan yang dihadapi oleh setiap mitra secara spesifik dan juga agar para mitra mendapatkan bayangan mengenai materi yang akan didapatkan.

Pada tahap selanjutnya, para tutor berdiskusi mengenai materi yang akan diberikan. Para tutor juga berdiskusi dan bertukar pikiran mengenai masalah yang 
dihadapi oleh mitra. Kemudian para tutor juga mempersiapkan solusi untuk permasalahan yang dihadapi oleh para mitra.

Pada tahap kelima ini kegiatan pengabdian kepada masyarakat dilakukan dengan mempertemukan para tutor dan mitra menggunakan forum googlemeet.

Tahap terakhir adalah melakukan evaluasi dan monitoring. Cara melakukan evaluasi dan monitoring ini adalah dengan memberikan kuesioner akhir mengenai kegiatan pengabdian kepada masyarakat menggunakan forum googlemeet dan membuka forum diskusi setelah acara selesai.

Kegiatan ini yang dimulai dari peninjauan lapangan hingga evaluasi dan monitoring menghabiskan waktu selama 5 bulan, yaitu dari bulan Februari 2020 hingga bulan Juni 2020.

\section{HASIL DAN PEMBAHASAN}

New normal adalah skenario yang dirancang oleh pemerintah yang bertujuan untuk mempercepat penanganan pandemik COVID-19 yang dilihat dari sisi kesehatan dan sisi social dan sisi ekonomi. Implementasi skenario new normal yang dirancang oleh pemerintah mempertimbangkan berbagai aspek yang mempengaruhi kehidupan dan tatanan sosoal masyarakat, namun pertimbangan skenario ini diutamakan dilihat dari studi epidemiologis dan kesiapan regional.

Membuka sektor UMKM dapat menjadi pilihan yang dipilih oleh pemerintah ketika akan memasuki fase new normal. Sektor UMKM dapat menjadi pilihan pertama dikarenakan Sektor UMKM memiliki dampak risiko kesehatan yang minim namun manfaat ekonomi yang dirasakan tinggi. Alasan sektor UMKM sebaiknya menjadi prioritas pemerintah dikarenakan sektor UMKM berkontribusi sebesar $60 \%$ dari ekonomi nasional dan menyerap $97 \%$ tenaga kerja di Indonesia. UMKM mampu meningkatkan konsumsi nasional yang selanjutnya akan berdampak pada pertumbuhan ekonomi nasional.

Strategi yang dapat di terapkan oleh UMKM dalam menghadapi kondisi new normal adalah:

1. Melakukan kembali riset pemasaran

Dengan melakukan riset pemasaran ulang, maka dapat diketahui strategi yang lebih stepat dalam rangka untuk memenuhi kebutuhan konsumen yang disesuaikan dengan segmentasi, target dan posisi perusahaan pada era new normal.

2. Mengevaluasi produk

Evaluasi produk muncul ketika memasuki era new normal, karena konsumen akan lebih berhati-hati menggunakan produk baru dan adanya kemungkinan konsumen akan beralih menggunakan produk yang lebih murah namun dengan kualitas standar. Hal ini dikarenakan konsumen akan lebih mengalokasikan dananya untuk mempersiapkan kemungkinan terjadinya krisis kembali.

3. Manajemen persediaan produk

Perusahaan perlu untuk mengintegrasikan antara jumlah pembelian bahan baku, jumlah produksi dan jumlah penjualan, sehingga akan dihasilkan jumlah persediaan yang tepat. 
4. Mengevaluasi harga

Pada era new normal, daya beli masyarakat akan suatu produk akan menurun. Hal ini dikarenakan kemampuan membeli produk yang menurun dan pertimbangan untuk mengalokasikan dana ke pos yan lain. Oleh karena itu, perusahaan sebaiknya mengevaluasi harga yang ditawarkan dengan menggunakan strategi seperti diskon dan bundling product.

5. Mengintegrasikan pengiriman

Dampak adanya COVID-19 ini adalah dengan diberlakukan PSBB (Pembatasan Sosial Berskala Besar) di beberapa daerah di Indonesia. Oleh karena itu, perusahaan perlu mengintegrasikan pengiriman produknya dengan menggunakan berbagai sarana transportasi dan media yang ada.

6. Menggunakan media social dan toko online

Perusahaan perlu untuk mengalihkan penjualan produknya dari yang bersifat offline menjadi online. Perusahaan dapat memanfaatkan media sosial dan aplikasi toko online untuk memasarkan produknya.

7. Mengalihkan pembayaran tunai ke non tunai

Perusahaan dapat menggunakan pelayanan keuangan digital untuk transaksi keuangannya, sehingga transaksi pembayaran menggunakan sistem non tunai. Perusahaan juga dapat menyediakan merchant-merchant pembayaran di toko mereka, sehingga transaksi pembayaran tunai dapat dikurangi.

8. Menjaga arus kas perusahaan

Arus kas merupakan unsur penting dalam berbagai bidang usaha, oleh karena itu perusahaan harus mampu menjaga perputaran uangnya. Perusahaan dapat memanfaatkan aplikasi pencatatan akuntasi untuk membantu dalam mengelola pembukuan perusahaan. Perusahaan juga dapat memanfaatkan pelayanan keuangan digital seperti transfer untuk pembayaran dan penagihan ke pihak ketiga.

9. Merevisi anggaran perusahaan

Perusahaan dapat memilah pos-pos pengeluaran yang menjadi prioritas dan melakukan penyesuaian anggaran.

10. Mengubah cara monitoring transaksi keuangan

Perusahaan harus mampu mengubah transaksi keuangan yang selama ini dilakukan secara offline menjadi online, sehingga dapat mengurangi kontak fisik dengan banyak orang.

Dalam menghadapi fase new normal, terdapat beberapa panduan kerja yang dapat diadopsi oleh UMKM sehingga keselamatan kerja tetap menjadi prioritas namun tetap memberikan kenyamanan bagi konsumen dan karyawan. Panduan kerja tersebut adalah:

1. Setiap karyawan dan konsumen wajib untuk menggunakan masker

2. Memberi jarak antar pelaku usaha/pegawai, serta memberi jarak dengan konsumen

3. Memeriksa suhu tubuh seluruh karyawan ketika awal kegiatan dan memeriksa suhu tubuh konsumen

4. Diberikan sekat akrilik bagi karyawan yang memerlukan meja kerja 
5. Apabila memungkinkan, karyawan bekerja di rumah (work from home) atau bekerja dengan sistem shift.

6. Menelurusi kondisi kesehatan pelaku usaha/ karyawan

7. Menggunakan platform media social (seperti: zoom, googlemeet, dll) jika akan melakukan pertemuan dengan pihak luar baik dengan konsumen, supplier maupun karyawan

8. Mengurangi cara pembayaran dengan uang tunai

9. Menyediakan pelayanan digital seperti transfer antar bank, mesin EDC.

10. Memasarkan produk secara online dengan menggunakan aplikasi seperti: tokopedia, bukalapak, dll

\section{KESIMPULAN DAN SARAN}

Pada era new normal ini UMKM sebaiknya menjadi prioritas pemerintah dikarenakan sektor UMKM berkontribusi sebesar $60 \%$ dari ekonomi nasional dan menyerap $97 \%$ tenaga kerja di Indonesia. UMKM mampu meningkatkan konsumsi nasional yang selanjutnya akan berdampak pada pertumbuhan ekonomi nasional. Strategi yang dapat di terapkan oleh UMKM dalam menghadapi kondisi new normal adalah dengan melakukan penyesuaian transaksi bisnis perusahaan yang bersifat konvensional dan memanfaatkan berbagai jejaring social sehingga akan membuat kontak fisik akan berkurang. Perusahaan juga dapat mengadopasi panduan keselamatan kerja yang tetap memberikan rasa aman dan nyaman bagi karyawan dan konsumen.

\section{DAFTAR PUSTAKA}

Ajimat, A., Sunarsi, D., \& Sidiq, F. (2020). Berwirausaha Memanfaatkan Media Sosial Pada Daerah Sepatan. ADI Pengabdian Kepada Masyarakat, 1(1), 69-76.

Baas, T. dan M. Schrooten. 2006. Relationship Banking and SMEs: A Theoretical Analysis. Small Business Economics, 27.

Basri, Y.Z. and M. Nugroho. 2009. Ekonomi Kerakyatan: Usaha Mikro, Kecil, dan Menengah. Jakarta: Penerbit Universitas Trisakti.

Das, A.K. and N.B. Dey. 2005. Financial Management and Analysis Practices in Small Business: An Exploratory Study in India. Working Paper, http://sbaer.uca. edu/research/icsb/2005/paper53.pdf.

Effendy, A. A., \& Sunarsi, D. (2020). Persepsi Mahasiswa Terhadap Kemampuan Dalam Mendirikan UMKM Dan Efektivitas Promosi Melalui Online Di Kota Tangerang Selatan. Jurnal Ilmiah MEA (Manajemen, Ekonomi, \& Akuntansi), 4(3), 702-714.

Haque, MG., Munawaroh, Sunarsi, D., (2020). Analysis of SMEs Culinary Marketing Strategy During Covid 19 Pancemic: A Study at "Sate Bebek Cilegon" Resto in Cilegon, Banten. International Journal of Education, Information Technology, and Others. Vol.3. Issue 2 
Hidayat, Rahmad. Utami, Issa Dyah dan Romadhani, Sari. 2011. Pengembangan Strategi Komunikasi Pemasaran Industri Kecil Menengah (IKM). CoverAge $\therefore$ Journal of Strategic Communication. Vol. 1 No. 2. Hal. 2005-221.

Indra dan Lestari, S. 2009. Kajian Efektivitas Model Promosi Pemasaran Produk Usaha Mikro Kecil dan Menengah (UMKM). Jurnal Pengkajian Koperasi dan UKM. Vol. 4. Hal. 116- 139.

Jati, H., B. Bala, dan O. Nisnoni. 2004. Menumbuhkan Kebiasaan Usaha Kecil Menyusun Laporan Keuangan. Jurnal Bisnis dan Usahawan, II (8), 210-218

Kirschenmann, K. and L. Norden. 2010. The Relation between Borrower Risk and Loan Maturity in Small Business Lending. Working paper. http://terberger. bwl.uni-annheim.de/fileadmin/images/mitarbeiter/ KirschenmannNorden /Aug2010.pdf

Lukiastuti, Fitri, et.al (2020). The Influence of Entrepreneur's Personal Characteristics on SMES Performance Mediated by Entrepreneurial Orientation. International Journal of Psychosocial Rehabilitation. Volume 24 - Issue 8

Mac an Bhaird, C. and B.M. Lucey. 2010. Determinants of Capital Structure in Irish SMEs. Small Business Economics, 35 (3), 357-375.

Mazanai, M. and O. Fatoki. 2012. Perceptions of Start-up Small and Medium-Sized Enterprises (SMEs) on the Importance of Business Development Services Providers (BDS) on Improving Access to Finance in South Africa. Journal of Social Science, 30 (1), 31-41.

Mehta, P., McAuley, D. F., Brown, M., Sanchez, E., Tattersall, R. S., Manson, J. J., \& HLH Across Speciality Collaboration. (2020). COVID-19: consider cytokine storm syndromes and immunosuppression. Lancet (London, England), 395(10229), 1033.

Murniati. 2002. Analisis Faktor-Faktor yang Mempengaruhi Penyiapan dan Penggunaan Informasi Akuntansi pada Pengusaha Kecil dan Menengah di Jawa Tengah. Tesis, Universitas Diponegoro.

Pinasti,M.2001.Penggunaan Informasi Akuntansi dalam Pengelolaan Usaha Para Pedagang Kecil di PasarTradisional Kabupaten Banyumas. Jurnal Ekonomi, Bisnis, dan Akuntansi, 1 (3).

Siregar, S.V., S.N. Harahap, dan Wasilah. 2011. Evaluasi Tantangan Penerapan Standar Akuntansi Entitas Tanpa Akuntabilitas Publik (SAK ETAP) untuk Usaha Kecil dan Menengah. Proposal Hibah RUUI

Van Hemert, P., E. Masurel, and P. Nijkamp. 2011. The Role of Knowledge Sources of SME's for Innovation Perception and Regional Innovation Policy. Working paper. http://dare.ubvu.vu.nl/ bitstream/1871/24072/1/ rm\%202011- 39.pdf.

Warsono, S. dan E. Murti. 2010. Akuntansi UMKM Ternyata Mudah Dipahami dan Dipraktikkan. Yogyakarta: Asgard Chapter Winarno.

World Health Organization. (2020). Coronavirus disease 2019 (COVID-19): situation report, 72 . 